\title{
An Alternative to Increase Accumulation of Phenolic Compound in Grapevine Callus Cultures: Chemical Mutagen Applications
}

\author{
Emine Sema CETiN ( $\square$ esema.cetin@yobu.edu.tr) \\ Bozok Universitesi https://orcid.org/0000-0001-7601-8491
}

\section{Selda DALER}

Yozgat Bozok University

\section{Research Article}

Keywords: Grapevine, mutagen, acridine orange, azacitidine, ethyl methanesulfonate, sodium azide, phenolic compound, anthocyanin

Posted Date: September 20th, 2021

DOI: https://doi.org/10.21203/rs.3.rs-883530/v1

License: (c) (i) This work is licensed under a Creative Commons Attribution 4.0 International License. Read Full License 


\section{Abstract}

This research was carried out to investigate the effects of chemical mutagen applications on producing phenolic compounds in calli obtained from leaf petiole explants of the Royal grape variety.

Petioles were cultured in B5 medium containing $0.5 \mathrm{mg} / \mathrm{L}$ benzyl amino purine and $0.5 \mathrm{mg} / \mathrm{L}$ indole acetic acid to obtain callus. Calli obtained during the period following planting were subcultured in the same culture conditions three times at one month intervals. In the fourth subculture, the calli were transferred to nutrient mediums with the same composition containing ethyl methanesulfonate, sodium azide, azacitidine and acridine orange in three different doses, $0.5 \mathrm{mM}, 1.0 \mathrm{mM}$, and $2.0 \mathrm{mM}$, and cultured in these mediums for 60,120 and 180 minutes. Then, they were cultured again for four weeks in mutagen-free nutrient mediums with the same content as their previous mediums. At the end of this period, calli were taken from their nutrient medium, and total phenolic compound, total flavanol, total flavonol and anthocyanin analyzes were performed.

As a result of the research, it has been determined that all mutagens applied are effective in increasing the production of phenolic compounds depending on the dose and time.

\section{Introduction}

Plants produce "primary metabolites" (carbohydrate, protein, fat, etc.), which are necessary for their growth and development, as well as "secondary metabolites" from the intermediate products of these metabolism pathways. These compounds produced by special metabolic pathways and generally classified according to biosynthesis methods are compounds that do not have direct effects on the vital functions of plants but determine quality criteria such as color, taste, and odor. Secondary metabolites are defined as compounds that play an active role in developing the defense mechanism of plants against microorganisms and herbivores and protect against various biotic and abiotic stresses (Wink, 1999; Theis and Lerdau, 2003). Although some of these compounds, which are extremely important in the adaptation of plants to their environment, are produced in relatively higher quantities, it is also known that they are generally produced in low quantities and that the production of some is limited to certain species and certain organs (Verpoorte et al., 1999; Sökmen and Gürel, 2001). It is known that compounds, which have important functions in the plant, also have a great role in human health (Kahkönen et al., 2001; Kahkönen et al., 2003; Rossi et al., 2003; Viljanen et al., 2004).

One of the most important members of secondary metabolites representing a rich group is phenolic compounds. These compounds are aromatic ring compounds containing at least one hydroxyl group and functional groups thereof with antioxidant properties. Phenolic compounds are known to inhibit the formation of low-density lipoproteins (Frankel et al., 1995), have protective effects against cardiovascular diseases (Renaud et al., 1999; Gronbaek et al., 2000), and are among the important secondary metabolites with their antimicrobial (Nychas et al., 2003, Göktürk Baydar et al., 2004) and anticarcinogenic (Zhao et al., 1999; Waffo-Teguo et al., 2001) properties. They also bind free radicals to 
themselves and prevent them from attacking nucleic acids, somatic cells, and the immune system (Han, 1997; Khalil et al., 2007). Also, these compounds are used in the cosmetic industry with their anti-aging effects.

Flavonoids, an important group of phenolic compounds, are responsible for many plant life-related functions as secondary metabolites in plants. They are the most common phenolic compounds in the human diet, and more than 5000 flavonoids have been identified (Bronze et al., 2012). Flavonoids are divided into six different classes. These are flavones (apigenin), flavonoids (eriodictyol, hesperetin, and naringenin), flavonols (quercetin, kaempferol, myricetin, and isorhamnetin), isoflavonoids (genistein, daidzein), anthocyanins (cyanidin, delphinidin, malvidin, pelargonidin, petunidin, peonidin) and flavanols (epicatechin, proanthocyanidins) (Peterson and Dwyer, 1998).

The most common flavonoid group in foods are flavanols, and they are colorless compounds found in most fruits. They take place as intermediates in flavonoid biosynthesis. They are systematically called flavan-3-ol because they contain an $-\mathrm{OH}$ group on the $\mathrm{C} 3$ atom (Aron et al., 2008). They are mostly found in glucoside form in plants. Approximately 450 flavonol glucosides have been identified (Corradini et al., 2011; Crozier et al., 2009). The main sources of flavonols are onions, garlic, cabbage, leeks, cauliflower, broccoli, blueberries, cherries, tomatoes, apples, and red grapes (Perez Vizcaino and Duarte, 2010).

Anthocyanins in the flavonoid class of phenolic compounds contain natural red, blue, and purple color pigments. Although 22 different anthocyanin types are known, the most important are delphinidin, malvidin, pelargonidin, peonidin, petunidin, and cyanidin. Anthocyanins can be used as natural food additives to increase the attractiveness of food and beverages by providing natural coloring on the one hand (Jackman et al., 1993), and in the food industry to increase the shelf life of foods on the other hand. Anthocyanins, like other phenolic compounds, are anticarcinogenic (Rossi et al., 2003) and antioxidant (Kahkönen et al., 2001; Kahkönen et al., 2003; Viljanen et al., 2004) and are used in the pharmaceutical industry (Zhang and Furusaki, 1999).

Various difficulties are encountered during the production of these compounds, which have a wide range of uses from plants under natural conditions. The main problems encountered are that the collection of these plants is sometimes difficult and expensive, the danger of extinction of some species as a result of the collection of rare plants from nature in large quantities, the quantity, and quality of the compounds are affected by climatic conditions or the need for large agricultural areas and intensive labor for the production of effective substances in economic amounts due to their synthesis at certain stages of development and in very small amounts. In recent years, studies have been carried out to ensure that these compounds can be obtained in high amounts and purity by in vitro techniques. Producing secondary metabolites with biotechnological methods has many advantages. With these methods, environmental factors (climate, geographical difficulties, seasonal restrictions) are eliminated, less land use is provided, the danger of extinction due to the collection of the plant from nature is prevented, the ability to produce sufficient amounts of economically valuable metabolites found in plants in low quantities, homogeneity, standard quality and efficiency in production, and effectiveness in 
understanding the biosynthesis mechanisms of metabolites are provided. The production of secondary metabolites with biotechnological methods can be done faster and more reliably than classical methods. Among in vitro methods, especially callus and cell culture techniques, enable the rapid and reliable production of secondary metabolites on a large scale compared to other methods. This advantage provided by in vitro techniques has led researchers to work on these issues. In one of these studies, Hovhannisyan et al. (2011) found that oleandrin, oleandrigenin, and odoroside compounds were stimulated in the callus culture of oleander; Çölgeçen et al. (2012) stated that in the iridescent flower (Centaurea tchihatcheffii), callus cultures and the production of flavonoids and terpenoids from secondary metabolite groups increased. Estrada Zuniga et al. (2012) stated that the content of fatty acids (lauric, myristic, pentadecanoic, palmitic, and stearic acids) and phenolic compounds increased in callus culture in Ibervillea sonorae, which is a succulent. Besher et al. (2014) recorded an increase in the production of tropane alkaloids, hyoscyamine, and scopolamine content in callus culture in henbane (Hyoscyamus aureus). Bibi et al. (2018) showed that the amount and antioxidant capacity of phenolic compounds and flavonoids among secondary metabolites increased in black cumin in callus culture; Arijanti and Suryaningsih (2019) found that the biosynthesis of gingerol, shogaol, and zingerone, which are secondary metabolites, increased in callus cultures of the ginger plant.

Studies have also shown that biotic or abiotic elicitors (drought, temperature, salinity, heavy metal, etc.) applied to plants in in vitro conditions cause significant increases in the number of secondary metabolites as a response of the stress mechanism in plants (Verporte et al., 2002; Commun et al., 2003; Vanisree ve Tsay, 2004; Grzegorczyk-Karolak et al., 2015; Sharma et al., 2015; Cardoso et al., 2019). It has been determined that various stress-inducing elicitors such as polysaccharides, jasmonic acid/methyl jasmonate, heavy metal, light radiation (Çetin, 2010), UV rays (Çetin, 2014; Çelik et al., 2020; Oğuz et al., 2020) can be successfully applied in the synthesis of secondary metabolites. In these studies, Bulgakov et al. (2002) recorded an increase in anthraquinone production with salicylic acid, methyl jasmonate, ethephon, and cantharidin applications in callus cultures of madder; Blando et al. (2005) obtained an increase in the number of cyanidin glucosides using jasmonic acid elicitor in cherry callus culture. Katerova et al. (2013) reported that UV-B and UV-C radiation stimulated plant secondary metabolite production in callus cultures; Kochan and Chmiel (2013) have managed to increase the production of ginsenocytes by using different photoperiods in ginseng callus culture. Benítez García et al. (2014) increased carotenoid production in callus cultures of marigold; Awad et al. (2014) applied methyl jasmonate and bacterial and fungal elicitors to the root cultures of Indian licorice and stated that the amount of glycyrrhizic acid increased. Alhasnawi et al. (2017) found that $\beta$-glucan and salt stress applications stimulated antioxidant accumulation in callus cultures of rice plants (Oryza sativa L.). In another study in this topic, Ullah et al. (2019) stated that UV-C radiation and melatonin applications in callus cultures of cress increase the biosynthesis of antioxidant and antidiabetic metabolites; Purwianingsih et al. (2019) reported that chitosan extract obtained from shrimp shell as an elicitor in callus cultures of Noni (Morinda citrifolia L.) plant increased the anthraquinone content. Apart from these stress-inducing elicitors, another factor that causes stress in plants is mutagens that cause mutation. 
Mutations can be obtained in three different applications as physical, chemical, and transposable. Physical mutagens are X-rays, Gamma rays (Co60, Sz137), Neutrons, Beta cathode rays, Alpha particles, and protons. Chemical mutagens are Diethyl sulfate (DES), ethyl methanesulfonate (EMS), methyl methane sulfate (MMS), ethyleneimine (EI), N-nitrous N-ethylurea (NEU), and azides. Chemical mutagens are generally suitable for generating micro mutations (Sağel, 1994). Transposable elements exist in different forms: transposons, retrotransposons, T-DNA, and retroviruses (Pakyürek, 2019). Chemical mutagens used in the mutation are divided into seven groups according to their activity patterns. These are basic compounds (5-bromine uracil, 5-bromodeoxyuridine, 2 amino purines); antibiotics (azeserin, mitomycin C, streptonigrin, actinomycin D), alkali compounds (such as EMS, ethyl-2-chloroethyl sulfide, ethylene oxide), azides (sodium azide), hydroxylamine, nitrite acid and acridines (acridine orange).

The application doses of mutagens depend on the type of mutagen and the material to be used. Some mutagens are lethal when used in high doses. Others cannot produce the desired mutations at low doses. The main reason for this is that chromosomes can repair weak mutations in their bodies over time. With the ability of chromosomes to repair at low doses, the desired mutations can be prevented. In this research, the effects of mutagen applications that cause stress in the plant on the production of phenolic compounds were investigated. Studies have shown that vine, grape, and products derived from grapes are rich in phenolic compounds (Revilla and Ryan, 2000; Murthy et al., 2002) and known to contain benzoic acids, hydroxycinnamic acids, stilbene derivatives (resveratrol), flavanols (catechin, epicatechin), flavonols (kaempferol, quercetin) and anthocyanins (Vinson and Hontz, 1995; Ghiselli et al., 1998). In this study, the grapevine was used as plant material. It is known that mutagen applications are mainly used in viticulture to create a genetic variation to improve mutation breeding, cluster density, berry color, aroma, seed properties, and ripening time, increase resistance to diseases and pests, and strengthen tolerance to environmental stress. This study aimed to increase the level of phenolic compounds by mutagen application in calli obtained from petiole of the Royal grape variety.

Within the scope of the research, chemical mutagens of acridine orange, azacitidine, ethyl methanesulfonate (EMS), and sodium azide were applied to calli at different concentrations and durations, and it was tried to reveal the effects of these mutagens on the total phenolic substance, total flavanol, total flavonol and anthocyanin content.

\section{Materials And Methods}

Materials: In the research, leaf petiole of the Royal grape variety used as plant material were used. Royal is a variety with very large and round berries it has purplish-black color, matures in the mid-late season, has a variety-specific aroma, and is for table use.

This study, which was carried out within the scope of a 2-year project, was carried out in the tissue culture laboratories, culture preparation, and culture development rooms within the Yozgat Bozok University Faculty of Agriculture, Department of Horticulture. 
Methods: The leaves of the Royal grape variety were taken from the collection vineyard of our university and brought to the laboratory. The petioles were separated and subjected to surface disinfection in a $15 \%$ commercial sodium hypochlorite solution for 10 minutes and then rinsed three times with sterile distilled water. They were then cut in lengths of approximately $0.5-1 \mathrm{~cm}$, inoculation in B5 (Gamborg et al., 1968) nutrient mediums containing $0.5 \mathrm{mg} / \mathrm{L}$ benzyl amino purin (BAP) and $0.5 \mathrm{mg} /$ indole acetic acid (IAA), and cultured at $25 \pm 1{ }^{\circ} \mathrm{C}$ under dark conditions. After the callus was obtained in these culture conditions, the calli were subcultured three more times at one-month intervals in the same environment and under the same culture conditions. After providing a sufficient amount of callus production for mutagen applications, calli were transferred to nutrient mediums containing acridine orange, azacitidine, EMS, and sodium azide at three different concentrations of $0.5 \mathrm{mM}, 1.0 \mathrm{mM}$, and $2.0 \mathrm{mM}$ and cultured in these mediums for 60, 120 and 180 minutes. Mediums without mutagen were used as a control. Then, they were cultured in mutagen-free nutrient mediums with the same content for four weeks at $25 \pm 1{ }^{\circ} \mathrm{C}$ under $16 / 8$ light/dark conditions. At the end of this period, the calli were taken from the nutrient medium they were in, and kept in a deep freezer at $-20^{\circ} \mathrm{C}$ until the analysis was done. Total phenolic compound, total flavanol, total flavonol, and anthocyanin analyzes were carried out to determine the effects of mutagen applications on phenolic substance production in calli.

Phenolic compound extractions: The extraction processes were made based on the method of Kiselev et al. (2007) to determine the total phenolic substance, total flavanol, and total flavonol amounts.

Determination of total phenolic compounds: Total phenolic compound analyzes were performed using Folin-Ciocalteu colorimetric method according to Singleton and Rossi (1965), and the readings were done at $765 \mathrm{~nm}$ wavelength in a spectrophotometer. The total phenolic compound amounts were determined as $\mathrm{mg} / \mathrm{g}$ fresh weight (FW) as gallic acid equivalent by using the curve prepared from the standard gallic acid solution.

Determination of total flavanols: Total flavanols were produced by using DMAC (dimethylaminocinnamaldehyde) method, according to Arnous et al. (2001). The results are given in the form of $\mathrm{mg} / \mathrm{g}(\mathrm{FW})$ as the equivalent of catechin by using the curve prepared from the catechin standard.

Determination of total flavonols: Total flavonols were made using Neu solution according to Dai et al. (1995). The number of total flavonols was determined in $\mathrm{mg} / \mathrm{g}(\mathrm{FW})$ as a rutin equivalent by using the curve prepared from the rutin standard.

Determination of anthocyanin: Anthocyanin analyzes were performed using Mcllvaine's buffer $(\mathrm{pH}=3)$ according to the method used by Qu et al. (2006). Spectrophotometer readings were done at a wavelength of $535 \mathrm{~nm}$, and anthocyanin amounts were calculated as color values (CV) according to the formula below.

$C V=0.1 \times$ absorbance $\times$ dilution factor 
Statistical Analysis: All applications and analyzes in the research were carried out in three replications. SPSS (20.0) statistical analysis program was used to evaluate numerical data, and Duncan's multiple range test was used to determine the differences between applications.

\section{Results And Discussion}

The study determined that chemical mutagens applied to calli positively affect the number of phenolic compounds, depending on the dose and time.

\section{Application of acridine orange}

The first of the chemical mutagens applied in the study was acridine orange, and it was determined that this application was effective on the total phenolic compound, total flavanol, total flavonol, and anthocyanins in different ways (Table 1). There are differences in metabolite accumulation according to the dose and duration of the mutagen in terms of total phenolic compound amount; It is seen that 60 minutes of $0.5 \mathrm{mM}$ dose and 60 and 180 minutes of $2.0 \mathrm{mM}$ dose are the most suitable combinations in terms of total phenolic compound. It is also noteworthy that this application increased the total phenolic compound content 16 times compared to the control of the same periods. In terms of total flavanols, a $0.5 \mathrm{mM} / 60$ minutes application was effective on total flavanol amounts and in total phenolic compounds $(0.022 \mathrm{mg} / \mathrm{g})$, and in the same period, 2.75 times more flavanol production was realized compared to the calli in the control group. In terms of total flavonols, 60 minutes application of $2.0 \mathrm{mM}$ dose, which is the highest dose, was determined as the combination, which was the only effective one among the applications, and 25 times more flavonols compared to the control group were obtained. In the anthocyanins determined in terms of color value, the highest increase in acridine orange application with a value of $25.015 \mathrm{CV} / \mathrm{g}$ was obtained from calli in the $1.0 \mathrm{mM} / 120 \mathrm{~min}$ group.

\section{Application of azacitidine}

The changes in phenolic compound contents of calli to which azacitidine mutagen was applied are presented in Table 2. As can be understood from the examination of the table, the application of $0.5 \mathrm{mM}$ azacitidine for 180 minutes provided the highest values in total phenolic, total flavanol, and total flavonol contents. In terms of total flavonol, it is seen that doses of $2.0 \mathrm{mM}$ are also effective for all periods. When an examination is made in terms of anthocyanin, it is seen that the highest anthocyanin values were obtained in 60 and 120 minutes of a $1.0 \mathrm{mM}$ dose and 60 and 180 minutes of a $2.0 \mathrm{mM}$ dose, and the values obtained here were approximately 20 times higher than the lowest content.

\section{Application of EMS}

When the effect of EMS application on phenolic compound contents in calli was examined, the highest total phenolic substance contents were obtained from the applications of 0.5 and $1.0 \mathrm{mM}$ doses for 180 minutes with 0.708 and $0.757 \mathrm{mg} / \mathrm{g}$ (Table 3). $1.0 \mathrm{mM}$ EMS application for 180 minutes was also the combination in which the highest flavanol content was obtained. Combinations of $0.5 \mathrm{mM} / 120 \mathrm{~min}$ and 
$2.0 \mathrm{mM} / 180$ min were the most effective groups in total flavonols. Anthocyanin contents were highest in combinations of $0.5 \mathrm{mM} / 60 \mathrm{~min}$ and $1.0 \mathrm{mM} / 120 \mathrm{~min}$.

\section{Application of Sodium azide}

Another mutagen whose effect was examined in the study is sodium azide. The administration of sodium azide at a dose of $1.0 \mathrm{mM}$ for 60 minutes increased the amount of total phenolic substances approximately 12 times $(0.733 \mathrm{mg} / \mathrm{g})$ compared to the control at the same time $(0.057 \mathrm{mg} / \mathrm{g})$. The application of $1.0 \mathrm{mM}$ sodium azide for 120 minutes resulted in high values in total flavanols and total flavonols. The highest value in anthocyanin $(19.433 \mathrm{CV} / \mathrm{g})$ was obtained when the highest dose of 2.0 mM was applied for 60 minutes. Like our study, Chandran and Pillai (2018) reported that the application of sodium azide in callus cultures of green chiretta increased secondary metabolite production.

When the study's results are evaluated collectively, the mutagen application of different durations and doses causes significant statistical differences in the amount of anthocyanin, total phenolic compound, total flavanol, and total flavonols in calli.

It was found that;

- The mutagen in which the best result was observed in terms of the total phenolic compound amount was Acridine orange with $0.912 \mathrm{mg} / \mathrm{g}$;

- In terms of total flavanols, the mutagen that provides the highest accumulation is Azacitidine with 0.023 $\mathrm{mg} / \mathrm{g}$, followed by Acridine orange with $0.022 \mathrm{mg} / \mathrm{g}$;

- The highest result in terms of total flavonol amount was obtained from Acridine orange mutagen with $0.100 \mathrm{mg} / \mathrm{g}$;

- The highest mutagen in terms of anthocyanin amount is EMS with 32,578 and $32,291 \mathrm{CV} / \mathrm{g}$.

Therefore, among the mutagens used, it can be said that sodium azide is insufficient in terms of promoting secondary metabolite accumulation compared to other mutagens in the applied doses and durations. However, it should be considered that it may show a greater effect in different dose and time trials.

Studies are using different mutagens to create chemical mutations in plants. Pathirana et al. (2014) applied 1\% EMS for 1 hour to calli obtained from petiole explants in kiwi; Krupa-Malkiewicz et al. (2017) investigated the effects of 2 different concentrations of EMS application of 0.5 and $5.0 \mathrm{mM}$ on calli in petunia for 60, 120 and 180 minutes; While Kannan et al. (2015) used sodium azide on calli in bahiagrass, Toyada et al. (2013) used EMS, 6-azacitidine and acridine orange mutagens to rose buds at concentrations of 50, 100 and $200 \mu \mathrm{g} / \mathrm{ml}$. Shah et al. (2019) also applied EMS to calli in the Hyoscyamus niger plant. The aim of these studies is not to directly increase the production of secondary metabolites but to create mutations for different purposes. In a study conducted to improve callus properties in vitro 
without creating mutations, Mohammed and Ibrahim (2016) applied UV-B and EMS to callus cultures of rice plants (Oryza sativa L.). The effects of the applications on callus formation and development were examined, and as a result of the research, it was stated that mutagen applications were effective on callus properties. There is an extremely limited number of studies investigating secondary metabolite accumulation by applying mutagen. In one of these studies, Chandran and Pillai (2018) applied sodium azide at a concentration of $0.01 \%$ for 3 hours in callus cultures of green chiretta (Andrographis paniculata). As a result of their research, they stated that sodium azide applications improved some callus properties compared to control and increased the production of andrographolide, neo andrographolide, 14-deoxy-11,12-dihydro andrographolide, and andrographonin positively.

Singh and Sharma (2020) stated that creating mutations may be effective in induction of secondary metabolite synthesis mechanism, the production of phenolic compound and cinnamoyl putrescine was increased in mutant cells of Nicotiana tabacum and Nicotiana glauca to which p-fluorophenylalanine was applied, and X-ray radiation was applied to cell cultures of Anisodus acutangulus to increase scopolamine production. Similarly, it has been stated that the biotin accumulation in Lavendula vera cell cultures is increased by irradiation of $\mathrm{y}$ rays; the somaclonals created by a mutation in Catharanthus roseus were used to increase the production of ajmalicin and serpentine. In a study in which pfluorophenylalanine was used as a mutagen to obtain cell lines with high efficiency in terms of phenolic production, it was reported that capsaicin production increased in Capsicum annuum cell cultures where p-fluorophenylalanine was applied (Singh and Sharma 2020).

\section{Conclusion}

The results obtained from our research show that chemical mutagens, which are used to create more genetic variation, can act as an elicitor in the callus cultures of the leaf of grapevine causing significant increases in the concentration of secondary metabolites.

It is thought that this research, which was carried out using different chemical mutagens in callus cultures, will constitute a reference to the researches on the biosynthesis of secondary metabolites with the use of chemical mutagens. However, it is thought that higher amounts of secondary metabolite production can be achieved by evaluating various doses and durations of different mutagens.

\section{Declarations}

\section{Acknowledgements}

E.S.C contributed to this work in the experimental design and setup, lab processing of samples, data analysis, manuscript writing and discussion. S.D contributed to lab processing of samples, data interpretation, manuscript writing and discussion. The authors read and approved the manuscript. This work was financially supported by the Yozgat Bozok University Department of Scientific Research Projects (6602b-ZF/17-136). 


\section{Conflict of interest}

The authors declare no conflict of interest

\section{References}

1. Ahmad, N., Rab, A., \& Ahmad, N. (2016). Light-induced biochemical variations in secondary metabolite production and antioxidant activity in callus cultures of Stevia rebaudiana (Bert). Journal of Photochemistry and Photobiology. B, 154, 51-56.

2. Alhasnawi, A.N., Zain, C.R.C.M., Kadhimi, A.A., Isahak, A., Mohamad, A. \& Yusoff, W.M.W. (2017). Accumulation of antioxidants in rice callus (Oryza sativa L.) induced by $\beta$-glucan and salt stress. AJCS 11(1):118-125.

3. Aoyagi, H., Okada, M., Akimoto, C., Katsuyama, H., Yoshida, S., Kusakabe, I. \& Tanaka, H. (1996). "Promotion effect of alginate on chitinase production by Wasabia japonica", Biotechnology Techniques, 10, 649-654.

4. Arijanti, S. \& Suryaningsih, D.R. (2019). Biosynthesis of secondary metabolites (gingerol, shogaol, and zingerone) from callus of three ginger varieties. Drug Invention Today, 11(2).

5. Arnous, A., Makris, D.P. \& Kefalas, P. (2001). Effect of principal polyphenolic components in relation to antioxidant characteristics of aged red wines, Journal of Agricultural and Food Chemistry, 49 (12), 5736-5742.

6. Aron, P.M., \& Kennedy, J.A. (2008). Flavan-3-Ols: Nature, Occurrence and Biological Activity. Mol Nutr Food Res. 52(1):79-104.

7. Aşçı, Ö.A., Demirci, T. \& Baydar, N.G. (2018). Effects of $\mathrm{NaCl}$ applications on root growth and secondary metabolite production in madder (Rubia tinctorum L.) root cultures. International Journal of Secondary Metabolite, 5:(3), 210-216.

8. Awad, V., Kuvalekar, A. \& Harsulkar, A. (2014). Microbial elicitation in root cultures of Taverniera cuneifolia (Roth) Arn for elevated glycyrrhizic acid production, Industrial Crops and Products, 54, 1316.

9. Bronze, M., Figueira, M. \& Mecha, E. (2012). Flavonoids and its Contribution to a Healthier Life. Handbook on Flavonoids: Dietary Sources, Properties and Health Benefits, Nova Biomedical pp. 197247.

10. Corradini, E., Foglia, P., Giansanti, P., Gubbiotti, R., Samperi, R. \& Lagana, A. (2011). Flavonoids: chemical properties and analytical methodologies of identification and quantitation in foods and plants. Nat Prod Res. 25(5):469-495.

11. Crozier, A., Jaganathb, B. \& Cliffordc, M. (2009). Dietary Phenolics: Chemistry, bioavailability and effects on health. Nat. Prod. Rep., 26:1001-1043.

12. Benítez García, I., Heredia, F., Vanegas Espinoza, P. \& Meléndez Martínez, A.J. (2014). Callus culture development of two varieties of Tagetes erecta and carotenoid production. Electronic Journal of Biotechnology 17(3). 
13. Besher, S., Al- Ammouri, Y. \& Murshed, R. (2014). Production of tropan alkaloids in the in vitro and callus cultures of Hyoscyamus aureus and their genetic stability assessment using ISSR markers. Physiol Mol Biol Plants, 20(3): 343-349.

14. Bibi, A., Khan, M.A., Adil, M. \& Mashwani, U.R. (2018). Production of callus biomass and antioxidant secondary metabolites in Black Cumin. The Journal of Animal \& Plant Sciences, 28(5): 1321-1328.

15. Blando, F., Scardino, A.P., De Bellis, L., Nicoletti, I. \& Giovinazzo, G. (2005). Characterization of in vitro anthocyanin producing sour cherry (Prunus cerasus L.) callus cultures, Food Research International, 38, 937-942.

16. Bulgakov, V.P. Tchernoded, G.K., Mischenko, N.P., Khodakovskaya, M.V., Glazunov, V.P., Radchenko, S.V., Zvereva, E.V., Fedoreyev, S.A. \& Zhuravlev, Y.N. (2002). Effect of salicylic acid, methyl jasmonate, ethephon and cantharidin on anthraquinone production by Rubia cordifolia callus cultures transformed with the rolB and rolC genes. Journal of Biotechnology 97, 213-221.

17. Cardoso, J.C., Oliveira, M.E.B.S. \& Cardoso, F.C. (2019). Advances and challenges on the in vitro production of secondary metabolites from medicinal plants. Horticultura Brasileira 37: 124-132.

18. Chandran, N.A. \& Pillai, P.R.U. (2018). In vitro studies on the effect of Sodium azide treatment on secondary metabolites production in Andrographis paniculata (Burm. f.) Nees. Journal of Pharmacognosy and Phytochemistry, 7(5): 2411-2415.

19. Commun, K., Mauro, M.C., Chupeau, Y., Boulay, M., Burrus, M. \& Jeandet, P. (2003). Phytoalexin production in grapevine protoplasts during isolation and culture, Plant Physiology and Biochemistry, 41, 317-323.

20. Cormier, F., Crevier, H.A. \& Do, C.B. (1990). Effect of sucrose concentration on accumulation of anthocyanins in grape (Vitis vinifera) cell suspensions, Canadian Journal of Botany, 68, 1822-1825.

21. Çelik, M., Keskin, N. \& Özdemir, F.A. (2020). The effects of UV irradiation and incubation time on in vitro phenolic compound production in 'Karaerik' grape cultivar. KSU J. Agric Nat. 23 (6): 1428-1434.

22. Çetin, E.S. (2010). Researches on the secondary metabolite production of grapevine by cell suspension culture. Ph.D. Thesis. Süleyman Demirel University Graduate School of Applied and Natural Sciences Department of Horticulture. p.132

23. Çetin, E.S. (2014). Induction of secondary metabolite production by UV-C radiation in Vitis vinifera L. Öküzgözü callus cultures. Biological Research, 4, 47(1): 37.

24. Çölgeçen, H., Koca, U., Yağcı, C., Toker, G., Toker, M.C. \& Vural, M. (2012). Callus induction and secondary metabolite production studies in Centaurea tchihatcheffii Fisch. \& C.A.Mey. Fabad J. Pharm. Sci., 37, 9-16.

25. Dai, G.H., Andary, C., Mondolot, L. \& Boubals, D. (1995). Involment of phenolic compounds in the resistance of grapevine callus to downy mildew (Plasmopara viticola). European Journal of Plant Pathology, 101, 541-547.

26. Estrada Zúñiga, M.E., Arano Varela, H., Buendía González, L. \& Orozco, J. (2012). Fatty Acıds, phenols content, and antioxidant activity in Ibervillea sonorae callus cultures. Revista Mexicana de Ingeniería Química, 11(1); 89-96. 
27. Frankel, E.N., Waterhouse, A.L. \& Teissedre, P.L. (1995). Principal phenolic phytochemicals in selected California wines and their antioxidant activity in inhibiting oxidation of human low-density lipoproteins, Journal of Agricultural and Food Chemistry, 43, 890-894

28. Gala, R., Mita, G. \& Caretto, S. 2005. Improving alpha-tocopherol production in plant cell cultures, Journal of Plant Physiology, 162, 782-784.

29. Gamborg, O.L., Miller, R.A. \& Okajima, K. (1968). Nutrient requirements of suspension cultures of soybean root cells, Experimental Cell Research, 50, 151-156.

30. Ghiselli, A., Nardini, M., Baldi, A. \& Scaccini, C. (1998). Antioxidant activity of different phenolic fractions separated from an Italian red wine, Journal of Agricultural and Food Chemistry, 46, 361367.

31. Göktürk Baydar, N., Özkan, G. \& Sağdıç, O. (2004). Total phenolic contents and antibacterial activities of grape (Vitis vinifera L.) extracts, Food Control, 15, 335-339.

32. Grassmann, J., Hippeli, S. \& Elstner, E.F. (2002). Plant's defence and its benefits for animals and medicine: role of phenolics and terpenoids in avoiding oxygen stress, Plant Physiology and Biochemistry, 40, 471-478.

33. Gronbaek, M., Becker, U., Johansen, D., Gottschau, A., Schnohr, P., Hein, H.O., Jensen, G. \& Sorensen, T.I.A. (2000). Type of alcohol consumed and mortality from all causes, coronary heart disease and cancer, Annual International Medicine, 133, 411-419.

34. Grzegorczyk-Karolak, I., Kuźma Ł. \& Wysokińska, H. (2015). The effect of cytokinins on shoot proliferation, secondary metabolite production and antioxidant potential in shoot cultures of Scutellaria alpina. Plant Cell, Tissue and Organ Culture, 122, 699-708.

35. Han, C. (1997). Screening of anticarcinogenic ingredients in tea polyphenols, Cancer Letters, 114, 153-158.

36. Hovhannisyan, N., Mkrumyan, M., Yesayan, A., Aroutiounian, R., Newman, R.A., Grigoryan, R., Sarkisyan, N. \& Gasparyan, G. (2011). Callus culture of oleander retains pharmacological activities of the plant. NPAIJ, 7(3), 137-146.

37. Jackman, R.L., Yada, R.Y., Tung, R.A. \& Speers, R.A. (1993). Anthocyanins as food colorants, Journal of Food Biochemistry, 11, 201.

38. Jin, J.H., Shin, J.H., Kim, J.H., Chung, I.S. \& Lee, H.J. (1999). Effect of chitosan elicitation and media compo-nents on the production of anthraquinone colorants in madder (Rubia akane Nakai) cell culture, Bio-technology and Bioprocess Engineering, 4, 300-304.

39. Kahkönen, M.P., Hopia, A.I. \& Heinonen, M. (2001). Berry phenolics and their antioxidant activity, Journal of Agricultural and Food Chemistry, 49, 4076- 4082.

40. Kahkönen M.P., Heinämäki J., Ollilainen V. \& Heinonen M. (2003). Berry anthocyanins: isolation, identification and antioxidant activities, Journal of the Science of Food and Agriculture, 83, 14031411

41. Kannan, B., Davila-Olivas, N.H., Lomba, P. \& Altpeter, F. (2015). In vitro chemical mutagenesis improves the turf quality of bahiagrass, Plant Cell, Tissue and Organ Culture, 120, 551-561. 
42. Kapoor, S., Bhardwaj, P., Raghuvanshi, R. \& Sood, H. (2018). Influence of light quality on growth, secondary metabolites production and antioxidant activity in callus culture of Rhodiola imbricata Edgew. Journal of Photochemistry and Photobiology B Biology 183.

43. Katerova, Z., Todorova, D., Tasheva, K. \& Sergiev, I. (2013). Influence of ultraviolet radiation on plant secondary metabolite production. Genetics and Plant Physiology, 2(3-4), 113-144.

44. Khalil, M.Y., Moustafa, A.A. \& Naguib, N.Y. (2007). Growth, phenolic compounds and antioxidant activity of some medicinal plants grown under organic farming condition, World Journal of Agricultural Sciences, 3 (4), 451-457.

45. Kiselev, K.V., Dubrovina, A.S., Veselova, M.V., Bulgakov, V.P., Fedoreyev, S.A. \& Zhuravlev, Y.N. (2007). "The rolB gene induced overproduction of resveratrol in Vitis amurensis transformed cells, Journal of Biotechnology, 128, 681-692.

46. Kochan, E. \& Chmiel, A. (2013). Callus of American ginseng (Panax quinquefolius) as a source of ginsenosides-medicinal secondary metabolites. Biological Lett., 50(1): 27-34.

47. Krupa Malkiewicz, M., Kosatka, A., Smolik, B. \& Sedzik, M. (2017). Induced mutations through EMS treatment and in vitro screening for salt tolerance plant of petunia $\times$ atkinsiana D. Don, Notulae Botanicae Horti Agrobotanici Cluj-Napoca, 1, 45.

48. Mohammed, R.K. \& ibrahim, K.M. (2016). Callus induction and proliferation as affected by EMS and UV-B mutagens in rice (Oryza sativa L.) genotypes. Iraqi Journal of Science, Special Issue, Part B, pp: 296-303.

49. Murthy, K.N.C., Singh, R.P. \& Jayaprakasha, G.K. (2002). Antioxidant activity of grape (Vitis vinifera) pomace extracts. Journal of Agricultural and Food Chemistry, 50, 5909-5914.

50. Nychas, G.J.E., Tassou, C.C. \& Skandamis, P. (2003). Making the most of herbs, spices and their active components, In: S. Roller (Ed.), Natural Antimicrobials for The Minimal Processing of Foods, 176-200.

51. Oğuz, D., Keskin, N. \& Özdemir, F.A. (2020). Induction of anthocyanin accumulation in callus culture of 'Karaerik' (Vitis vinifera L.) by ultraviolet irradiation effect. Turkish Journal of Agricultural Research, 7(1): 96-104.

52. Paksereshta, G., Kahrizi, D., Mansouric, M, Ghorbanic, T. \& Kazemic, N. (2016). Study of callus induction and cell culture to secondary metabolite production in Hyssopus officinalis L. Journal of Reports in Pharmaceutical Sciences, 5(2), 104-111.

53. Pakyürek, M. (2019). Mutation breeding: Applications in the field of fruit. Ispec 5 th International Conference on Engineering \& Natural Sciences, December 20-22, Van, TURKEY

54. Pathirana, R., Deroles, S., Hoeata, K., Montefiori, M., Tyson, J., Wang, T., Datson, P.M. \& Hellens, R.P. (2016). "Fast-tracking kiwifruit breeding through mutagenesis", XXIX International Horticultural Congress on Horticulture: Sustaining Lives, Livelihoods and Landscapes (IHC2014): International Symposium on Plant Breeding in Horticulture, 10.17660/ActaHortic.2016.1127.34.

55. Perez-Vizcaino, F. \& Duarte, J. (2010). Flavonols and cardiovascular disease. Mol Aspects of Med., 31,478-494. 
56. Peterson, J. \& Dwyer, J. (1998). Flavonoids, dietary occurence and biochemical activity. Nutrition Research, 18(12): 1995-2018.

57. Purwianingsih, W., Hidayat, R.Y. \& Rahmat, A. (2019). Increasing anthraquinone compounds on callus leaf Morinda citrifolia (L.) by elicitation method using chitosan shell of shrimps (Penaeus monodon). Journal of Physics: Conference Series, 1280(2).

58. Qu, J.G., Zhang, W., Jin, M.F. \& Yu, X.J. (2006). Effect of homogeneity on cell growth and anthocyanin biosynthesis in suspension cultures of Vitis vinifera, Chinese Journal of Biotechnology, 22 (5), 805810.

59. Rajendran, L., Ravishankar, G.A., Venkataraman, L.V. \& Prathiba, K.R. (1992). Anthocyanin production in callus cultures of Daucus carota as influence by nutrient stress and osmoticum. Biotechnology Letters 14, 707-712.

60. Renaud, S.C., Guéguen, R., Schenker, J.D. \& Houtaud, A. 1999. Alcohol and mortality in middle-aged men from eastern France, Epidemiology, 9, 184- 188.

61. Revilla, E. \& Ryan, J.M. (2000). Analysis of several phenolic compounds with potential antioxidant properties in grape extracts and wines by high-performance liquid chromatography-photodiode array detection without sample preparation, Journal of Chromatography A, 881, 461-469.

62. Rossi, A., Serraino, I., Dugo, P., Di Paola, R., Mondello, L., Genovese, T., Morabito, D., Dogo, G., Sautebin, L., Caputi, A.P. \& Cuzzocrea, S. (2003). Protective effects of anthocyanins from Blackberry in a rat model of acute lang inflammation, Free Radical Research, 37, 891-900.

63. Sağel, Z. (1994). Chemical Mutagens and Their Application in Plant Breeding. Journal of Field Crops Central Research Institute, 3(1-2):87-93.

64. Shah, D., Kamili, A.N., Wani, A.A., Dar, R., Nazır, N.,Tyub, S. \& Mir, M.Y. (2019). EMS induced point mutations in 18S rRNA gene of Hyoscyamus niger L. An important medicinal plant of Kashmir Himalaya. Pak. J. Bot., 51(3): 949-955.

65. Sharma, A., Slathia, S., Gupta, D., Handa, N., Choudhary, S.P., Langer, A. \& Bhardwaj, R. (2015). Antifungal and antioxidant profile of ethnomedicinally important liverworts (Pellia endiviifolia and Plagiochasma appendiculatum) used by indigenous tribes of district Reasi: North West Himalayas Proceedings of the National Academy of Sciences. India Section B: Biological Sciences. 85: 2, 571579.

66. Singh, B. \& Sharma, R.S. (2020). Mutagenesis.Chapter

3.9. https://doi.org/10.1002/9783527825578.c03-09. 27 March 2020.

67. Singleton, V.L. \& Rossi, J.R. (1965). Colorimetry of total phenolics with phosphomolybdicphosphotungstic acid, American Journal of Enology and Viticulture, 16, 144-158.

68. Sökmen, A. \& Gürel, E. (2001). Sekonder Metabolit Üretimi, (Editörler M. Babaoğlu, E. Gürel, S. Özcan), Bitki Biyoteknolojisi Cilt I Doku Kültürü ve Uygulamaları, S.Ü. Vakfı Yayınları, Konya, s. 211-261.

69. Theis, N. \& Lerdau, M. (2003). The Evolution of Function in Plant Secondary Metabolites, International Journal of Plant Sciences, 162, 93-102. 
70. Toyoda, H., Nonomura, T. \& Matsuda, Y. (2013). Callus-mediated plant regeneration from morphologically changed petals produced by mutagen-treated apical rose buds. VIII International Symposium on In Vitro Culture and Horticultural Breeding, 487-490.

71. Ullah, M.A., Tungmunnithum, D., Garros, L., Drouet, S., Hano, C. \& Abbasi, B.H. (2019). Effect of ultraviolet-C radiation and melatonin stress on biosynthesis of antioxidant and antidiabetic metabolites produced in in vitro callus cultures of Lepidium sativum L. Int. J. Mol. Sci., 20, 1787; doi:10.3390/ijms20071787.

72. Vanisree, M. \& Tsay, H.S. (2004). Plant cell cultures an alternative and efficient source for the production of biologically important secondary metabolites, International Journal of Applied Science and Engineering, 2, 29-48.

73. Verpoorte, R., Contin, A. \& Memelink, J. (2002). Biotechnology for the production of plant secondary metabolites. Phytochemistry Reviews, 1: 13-25.

74. Verpoorte, R., Heijden, R., Hoopen, H.J.G. \& Memelink, J. (1999). Metabolic engineering of plant secondary metabolite pathways for the production of fine chemicals, Biotechnology Letters, 21, 467479 .

75. Viljanen, K., Kivikari, R. \& Heinonen, M. (2004). Protein-lipid interactions during liposome oxidation with added anthocyanin and other phenolic compounds, Journal of Agricultural and Food Chemistry, 52 (5), 1104-1111.

76. Vinson, J.A. \& Hontz, B.A. (1995). Phenol Antioxidant Index: Comparative antioxidant effectiveness of red and white wines, Journal of Agricultural and Food Chemistry, 43, 401-403.

77. Waffo Teguo, P., Hawthorne, M.E., Cuendet, M., Merillon, J.M., Kinghorn, A.D., Pezzuto, J.M. \& Mehta, R.G. (2001). Potential cancer-chemopreventive activities of wine stilbenoid and flavans extracted from grape (Vitis vinifera) cell cultures, Nutrition and Cancer, 40, 173-179.

78. Wink, M. (1999). Biochemistry, Role and Biotechnology of Secondary Metabolites. In: "Function of plant secondary metabolites and their exploitation in biotechnology. Sheffield Academic Press and CRC Press, Annual Plant Reviews, 3, 1-16.

79. Zhang, W. \& Furusaki, S. (1999). Production of anthocyanin by plant cell cultures, Biotechnology and Bioprocess Engineering, 4, 231-252.

80. Zhao, J., Wang, J., Chen, Y. \& Agarwal, R. (1999). Anti-tumor promoting activity of a polyphenolic fraction isolated from grape seeds in the mouse skin two stage initiation promotion protocol and identification of procyanidin B5-3-gallate as the most effective antioxidant constituent, Carcinogenesis, 20, 1737-1745.

\section{Tables}

Table 1. Effects of acridine orange application on phenolic compound production 


\begin{tabular}{|c|c|c|c|c|c|}
\hline $\begin{array}{l}\text { Dose } \\
\text { (mM) }\end{array}$ & $\begin{array}{l}\text { Time } \\
\text { (min) }\end{array}$ & $\begin{array}{l}\text { Total phenolic (mg/g } \\
\text { GAE) }\end{array}$ & $\begin{array}{l}\text { Total flavanols }(\mathrm{mg} / \mathrm{g} \\
\mathrm{CE})\end{array}$ & $\begin{array}{l}\text { Total } \\
\text { flavonols } \\
\text { (mg/g RE) }\end{array}$ & $\begin{array}{l}\text { Anthocyanin } \\
\text { (CV/g) }\end{array}$ \\
\hline \multirow[t]{3}{*}{0.0} & 60 & $0.057 c^{*}$ & $0.008 \mathrm{f}$ & $0.004 \mathrm{~b}$ & 1.352 ef \\
\hline & 120 & $0.010 \mathrm{c}$ & $0.007 \mathrm{~g}$ & $0.003 \mathrm{~b}$ & $2.456 \mathrm{~d}-\mathrm{f}$ \\
\hline & 180 & $0.055 \mathrm{c}$ & $0.010 \mathrm{de}$ & $0.007 \mathrm{~b}$ & $3.144 \mathrm{c}-\mathrm{f}$ \\
\hline \multirow[t]{3}{*}{0.5} & 60 & $0.807 \mathrm{a}$ & 0.022 a & $0.003 \mathrm{~b}$ & $12.085 b$ \\
\hline & 120 & $0.132 \mathrm{c}$ & $0.010 \mathrm{de}$ & $0.003 \mathrm{~b}$ & $6.924 \mathrm{c}$ \\
\hline & 180 & $0.129 \mathrm{c}$ & $0.007 \mathrm{~g}$ & $0.005 b$ & $6.241 \mathrm{~cd}$ \\
\hline \multirow[t]{3}{*}{1.0} & 60 & 0.192 bc & $0.010 \mathrm{de}$ & $0.004 \mathrm{~b}$ & 5.056 c-e \\
\hline & 120 & $0.166 \mathrm{bc}$ & 0.009 ef & $0.005 b$ & $25.015 \mathrm{a}$ \\
\hline & 180 & $0.092 \mathrm{c}$ & $0.010 \mathrm{de}$ & $0.005 b$ & $0.443 \mathrm{f}$ \\
\hline \multirow[t]{3}{*}{2.0} & 60 & $0.912 \mathrm{a}$ & $0.016 \mathrm{~b}$ & $0.100 \mathrm{a}$ & 1.340 ef \\
\hline & 120 & $0.361 \mathrm{~b}$ & $0.014 \mathrm{c}$ & $0.013 b$ & 1.207 ef \\
\hline & 180 & $0.786 a$ & $0.011 \mathrm{~d}$ & $0.002 b$ & $5.201 \mathrm{c}-\mathrm{e}$ \\
\hline
\end{tabular}

*There is a difference between the means with different letters in the same column $(p<0.05)$

Table 2. Effects of azacitidine application on phenolic compound production 


\begin{tabular}{|c|c|c|c|c|c|}
\hline $\begin{array}{l}\text { Dose } \\
\text { (mM) }\end{array}$ & $\begin{array}{l}\text { Time } \\
\text { (min) }\end{array}$ & $\begin{array}{l}\text { Total phenolic (mg/g } \\
\text { GAE) }\end{array}$ & $\begin{array}{l}\text { Total flavanols }(\mathrm{mg} / \mathrm{g} \\
\mathrm{CE})\end{array}$ & $\begin{array}{l}\text { Total } \\
\text { flavonols } \\
\text { (mg/g RE) }\end{array}$ & $\begin{array}{l}\text { Anthocyanin } \\
\text { (CV/g) }\end{array}$ \\
\hline \multirow[t]{3}{*}{0.0} & 60 & $0.093 \mathrm{e}-\mathrm{g}^{*}$ & $0.007 \mathrm{de}$ & $0.003 \mathrm{c}$ & $6.110 \mathrm{~cd}$ \\
\hline & 120 & $0.063 \mathrm{fg}$ & $0.015 \mathrm{c}$ & $0.005 b c$ & $4.856 \mathrm{~d}$ \\
\hline & 180 & $0.034 \mathrm{~g}$ & $0.006 \mathrm{de}$ & $0.003 \mathrm{c}$ & $4.768 d$ \\
\hline \multirow[t]{3}{*}{0.5} & 60 & 0.097 e-g & $0.008 \mathrm{~d}$ & $0.007 \mathrm{bc}$ & $6.033 \mathrm{~cd}$ \\
\hline & 120 & $0.132 \mathrm{e}$ & $0.007 \mathrm{de}$ & $0.002 \mathrm{c}$ & $1.951 \mathrm{~d}$ \\
\hline & 180 & $0.677 \mathrm{a}$ & $0.023 \mathrm{a}$ & $0.029 a$ & $3.989 \mathrm{~d}$ \\
\hline \multirow[t]{3}{*}{1.0} & 60 & $0.049 \mathrm{fg}$ & $0.008 \mathrm{~d}$ & $0.002 \mathrm{c}$ & $21.682 \mathrm{a}$ \\
\hline & 120 & 0.104 ef & $0.007 \mathrm{de}$ & $0.005 b c$ & $20.800 \mathrm{a}$ \\
\hline & 180 & $0.602 \mathrm{~b}$ & $0.019 \mathrm{~b}$ & $0.007 \mathrm{bc}$ & $13.252 \mathrm{~b}$ \\
\hline \multirow[t]{3}{*}{2.0} & 60 & $0.309 \mathrm{~d}$ & $0.014 \mathrm{c}$ & $0.029 a$ & $22.204 \mathrm{a}$ \\
\hline & 120 & $0.145 \mathrm{e}$ & $0.015 \mathrm{c}$ & $0.023 a$ & $11.031 \mathrm{bc}$ \\
\hline & 180 & $0.530 \mathrm{c}$ & $0.005 \mathrm{e}$ & $0.020 a b$ & $20.544 \mathrm{a}$ \\
\hline
\end{tabular}

*There is a difference between the means with different letters in the same column $(p<0.05)$

Table 3. Effects of EMS application on phenolic compound production 


\begin{tabular}{|c|c|c|c|c|c|}
\hline $\begin{array}{l}\text { Dose } \\
\text { (mM) }\end{array}$ & $\begin{array}{l}\text { Time } \\
\text { (min) }\end{array}$ & $\begin{array}{l}\text { Total phenolic (mg/g } \\
G A E)\end{array}$ & $\begin{array}{l}\text { Total flavanols }(\mathrm{mg} / \mathrm{g} \\
\text { CE) }\end{array}$ & $\begin{array}{l}\text { Total } \\
\text { flavonols } \\
\text { (mg/g RE) }\end{array}$ & $\begin{array}{l}\text { Anthocyanin } \\
\text { (CV/g) }\end{array}$ \\
\hline \multirow[t]{3}{*}{0.0} & 60 & $0.060 e^{\star}$ & $0.006 \mathrm{e}$ & $0.007 \mathrm{bc}$ & 8.399 c-e \\
\hline & 120 & $0.067 \mathrm{e}$ & 0.010 b-e & $0.006 \mathrm{bc}$ & $5.186 \mathrm{~d}-\mathrm{f}$ \\
\hline & 180 & $0.045 \mathrm{e}$ & $0.007 \mathrm{e}$ & $0.003 \mathrm{c}$ & $5.702 \mathrm{c}-\mathrm{f}$ \\
\hline \multirow[t]{3}{*}{0.5} & 60 & $0.625 b c$ & $0.013 b$ & $0.013 \mathrm{bc}$ & $32.578 a$ \\
\hline & 120 & $0.299 d$ & $0.006 \mathrm{e}$ & $0.030 \mathrm{a}$ & 2.930 ef \\
\hline & 180 & $0.708 a b$ & $0.012 b c$ & $0.007 \mathrm{bc}$ & 0.340 ef \\
\hline \multirow[t]{3}{*}{1.0} & 60 & $0.064 \mathrm{e}$ & $0.007 \mathrm{e}$ & $0.005 \mathrm{bc}$ & 7.549 c-e \\
\hline & 120 & $0.124 \mathrm{e}$ & $0.006 \mathrm{e}$ & $0.002 \mathrm{c}$ & $32.291 \mathrm{a}$ \\
\hline & 180 & $0.757 a$ & $0.021 \mathrm{a}$ & $0.011 b c$ & $11.191 \mathrm{~b}-\mathrm{d}$ \\
\hline \multirow[t]{3}{*}{2.0} & 60 & $0.543 \mathrm{c}$ & $0.011 \mathrm{~b}-\mathrm{d}$ & $0.006 \mathrm{bc}$ & $12.685 b c$ \\
\hline & 120 & $0.168 \mathrm{e}$ & 0.009 c-e & $0.003 \mathrm{c}$ & $12.403 \mathrm{bc}$ \\
\hline & 180 & $0.068 \mathrm{e}$ & $0.008 \mathrm{de}$ & $0.019 a b$ & $17.346 \mathrm{~b}$ \\
\hline
\end{tabular}

*There is a difference between the means with different letters in the same column $(p<0.05)$

Table 4. Effects of sodium azide application on phenolic compound production 


\begin{tabular}{|c|c|c|c|c|c|}
\hline $\begin{array}{l}\text { Dose } \\
\text { (mM) }\end{array}$ & $\begin{array}{l}\text { Time } \\
\text { (min) }\end{array}$ & $\begin{array}{l}\text { Total phenolic (mg/g } \\
G A E)\end{array}$ & $\begin{array}{l}\text { Total flavanols }(\mathrm{mg} / \mathrm{g} \\
\text { CE) }\end{array}$ & $\begin{array}{l}\text { Total } \\
\text { flavonols } \\
\text { (mg/g RE) }\end{array}$ & $\begin{array}{l}\text { Anthocyanin } \\
\text { (CV/g) }\end{array}$ \\
\hline \multirow[t]{3}{*}{0.0} & 60 & $0.057 d^{*}$ & $0.004 \mathrm{e}$ & $0.003 \mathrm{c}$ & 5.785 c-e \\
\hline & 120 & $0.032 \mathrm{~d}$ & $0.009 \mathrm{c}$ & $0.002 \mathrm{c}$ & $10.002 \mathrm{~b}-\mathrm{d}$ \\
\hline & 180 & $0.049 \mathrm{~d}$ & $0.009 c$ & $0.003 \mathrm{c}$ & $9.276 b-d$ \\
\hline \multirow[t]{3}{*}{0.5} & 60 & $0.073 d$ & $0.006 \mathrm{de}$ & $0.008 \mathrm{bc}$ & $2.229 \mathrm{e}$ \\
\hline & 120 & $0.078 \mathrm{~d}$ & $0.008 \mathrm{c}$ & $0.008 \mathrm{bc}$ & $5.010 \mathrm{de}$ \\
\hline & 180 & $0.104 \mathrm{~d}$ & $0.009 \mathrm{c}$ & $0.005 \mathrm{c}$ & $11.659 \mathrm{bc}$ \\
\hline \multirow[t]{3}{*}{1.0} & 60 & $0.733 a$ & $0.014 b$ & $0.017 \mathrm{bc}$ & $2.559 \mathrm{e}$ \\
\hline & 120 & $0.263 \mathrm{c}$ & $0.016 a$ & $0.050 \mathrm{a}$ & 8.582 b-d \\
\hline & 180 & $0.409 b$ & $0.009 c$ & $0.025 b$ & $12.171 b$ \\
\hline \multirow[t]{3}{*}{2.0} & 60 & $0.088 d$ & $0.007 \mathrm{~cd}$ & $0.004 \mathrm{c}$ & $19.433 \mathrm{a}$ \\
\hline & 120 & $0.126 d$ & $0.007 \mathrm{~cd}$ & $0.002 \mathrm{c}$ & $1.991 \mathrm{e}$ \\
\hline & 180 & $0.113 d$ & $0.012 b$ & $0.025 b$ & $3.978 \mathrm{de}$ \\
\hline
\end{tabular}

*There is a difference between the means with different letters in the same column $(p<0.05)$ 